University for Business and Technology in Kosovo

UBT Knowledge Center

UBT International Conference

2016 UBT International Conference

Oct 28th, 9:00 AM - Oct 30th, 5:00 PM

\title{
Professional access of woodworking engineers to the labor market
}

\author{
Ramadan Topuzi \\ Agricultural University of Tirana, dan_topuzi@live.it
}

Arben Bejtja

Agricultural University of Tirana, arbenbejtja@yahoo.fr

Leonidha Peri

Agricultural University of Tirana, leonidha.peri@ubt.edu.al

Follow this and additional works at: https://knowledgecenter.ubt-uni.net/conference

Part of the Architecture Commons

\section{Recommended Citation}

Topuzi, Ramadan; Bejtja, Arben; and Peri, Leonidha, "Professional access of woodworking engineers to the labor market" (2016). UBT International Conference. 64.

https://knowledgecenter.ubt-uni.net/conference/2016/all-events/64

This Event is brought to you for free and open access by the Publication and Journals at UBT Knowledge Center. It has been accepted for inclusion in UBT International Conference by an authorized administrator of UBT Knowledge Center. For more information, please contact knowledge.center@ubt-uni.net. 
Book of Proceedings

International Conference on Architecture and Spatial Planning

\title{
Professional access of woodworking engineers to the labor market
}

\author{
Ramadan Topuzi ${ }^{1}$, Arben Bejtja ${ }^{1}$, Leonidha Peri ${ }^{1}$ \\ ${ }^{1}$ Agricultural University of Tirana, Department of Wood Industry, \\ Tirana-Albania \\ dan_topuzi@live.it, arbenbejtja@yahoo.fr, leonidha.peri@ubt.edu.al
}

\begin{abstract}
In the Wood Industry Department at Agricultural University of Tirana, wood processing engineers have been graduating for years. Faculty performs its mission through trainings provided for the student during the learning process and practice until his graduation. This is considered as the fulfillment of institutional responsibility as there is no possibility of their employment management. The private sector constitutes real employment opportunities for Wood Processing engineers in Albania. The wood industry in Albania (after '90) was transformed from a centralized industry to free enterprise. Today it is mainly organized in small to medium enterprises, which produce and trade furniture and other wood products, with a geographical distribution throughout the territory. This is the main labor market for the wood processing engineers.

This study aims to present a clear picture of the labor market of the wood industry in Albania and adaptation of wood processing engineers with its continuous development.

The study is based on the analysis of a significant number of structured questionnaires for this purpose, with data collected through the face to face surveys. The sample used is intentional (improbable) where only the engineers surveyed, who are the main target, are 51.

After a thorough analysis of the data obtained it was found that: A significant proportion of engineers continue to contribute to the field of their studies. Engineers result; employed in management positions and a good portion of them are entrepreneurs.

Respondents are of the opinion that through the assessment of the curricula can be contoured also the profile of the engineer needed in this market. To be closer to the market, the faculty should prepare Wood Processing engineers who are professionally skilled and capable in terms of knowledge of new technologies in the field of architecture, interior design and woodworking technology. They must have applicable professional knowledge, updated to technological innovations in continuous improvement.
\end{abstract}

Keywords: curriculum, production subject, wood processing engineer.

\section{Introduction}

Wood processing tradition in Albania originates before the XII ${ }^{\text {th }}$ century, where there was a significant progress in the art of painting (in churches) and wood carvings. The first development signs date back 
to the second half of the $\mathrm{XIX}^{\text {th }}$ century, with the construction of water sawmills (initially in Korca and Kolonje). The wood processing industry in Albania made its first steps in 1946.

Wood processing entities were established in Albania after the changes of the 90s. Albania inherited a wood processing industry organized in factories and combines from the previous regime. Some of them were privatized and gradually adjusted to the market economy and continued to produce for the domestic and foreign market. Some other engineers, specialists for reasons related to their profession, gradually began their private activities.

In the Wood Industry Department of the Faculty of Forestry Sciences at the Agricultural University of Tirana, a significant number of wood processing engineers have been graduated over the years. The Faculty operates on the basis of a curricula developed by the academic staff, and approved by the Ministry of Education. Programs are drafted by the professor of the curricula or a group of professors; they are reviewed and approved by the head of the department or the dean. Meanwhile a part of the engineers graduated in this faculty, continue to contribute to the field for which they have studied. University is an institution of higher education operating in the field of education, scientific research, creative and professional activities. Universities function and are accredited in accordance with the "Law on Higher Education". The faculty carries out its mission through the training provided to the student throughout the learning process, practices, etc. until its graduation. This is considered a fulfillment of the duties and / or responsibilities of the entire institution, unable to control their employment / performance. The problems that arise consist of: Where will they be employed? What are the market demands? How many engineers are required? How will they be recruited? Etc. Wood Processing engineers can find employment opportunities in state and private institutions. Employment opportunities in state institutions remain scarce. Practically, it is the private sector which is the main labor market for the profiled nature of this profession.

The domestic labor market remains the main potential of the Wood Processing engineers and the private manufacturing entities of wood processing / furniture constitute the main employment opportunities for them(gradually established businesses after the 90s). However, the need for wood processing engineers in this market is yet to be seen.

How much informed and trained are they? Is their professional and scientific profile appropriate to get involved in this market? Has he obtained at the faculty where he has studied all the knowledge necessary to be worthy of the targeted workplace? Do his knowledge and background adapt to the current conditions and the needs of the labor market?

The object of the study is:

a) Main manufacturing entities of wood processing industry in Albania.

b) Comparison of the curricula of the Department of Wood Industry, with the actual needs of the labor market.

The aim of this study is: the establishment of a clear picture of the labor market of the wood industry in Albania, to see the adaptation of woodworking engineers to the continuous development of the labor market.

The study is based on analysis of a significant number of structured questionnaires for this purpose. The questionnaire used for the survey starts with general questions, it follows with questions for the curricula and closes with open-ended questions to assess respondents' opinions.

The questionnaires consist of specific questions about the curricula of the Department of Wood Industry. The questionnaire approximates a usable format to enable the creation of an engineer profile closer to labor market demands. There were conducted 250 surveys through the face to face survey method.

The sample used is a purposive sample and not a probabilistic one. Respondents are administrators of manufacturing entities, executives, economists, etc. As regards the professional training of the 
Book of Proceedings

International Conference on Architecture and Spatial Planning

respondents, the latter result being; wood processing engineers, architects, economists, of university education (unspecified) and of secondary education.

\section{Methodology}

The main basis of this study; data collection through questionnaires, through which, the respondents express their opinion on the wood processing engineers.

The methodology followed for the implementation of this study is:

- Study of the curriculum used in the Department of Wood Industry and its evolution.

- Identification of key entities operating in the wood processing industry in Albania.

- Development of questionnaires necessary for this purpose, through which, all respondents give their assessment regarding the curricula.

- Direct contacting of respondents (Directors / business managers, engineers, economists, etc.), on site (to manufacturing entities).

- Completion of questionnaires through interviews / face-to-face surveys

- Data Processing and Analysis

\section{Data analysis}

For the research were selected 250 leading businesses in Albania, a total of 900 manufacturing entities with approximately 10000 employees. The data collected on site for the wood industry in Albania found that wood processing engineers constitute one of its essential factors. Of the surveyed entities 75 are engineers who hold entrepreneurial or management positions. While, 94 others are still needed. There have been surveyed 51 wood processing engineers, who have given their opinion on the curricula, the current Albanian labor market and trends.

Table 1. Occupation of the respondents.

\begin{tabular}{|l|l|c|c|}
\hline No. & Occupation of the respondents & $\begin{array}{c}\text { Number of } \\
\text { respondents }\end{array}$ & $\begin{array}{c}\text { Percentage of } \\
\text { respondents }\end{array}$ \\
\hline 1 & Wood Processing Engineers & 51 & 20.4 \\
\hline 2 & Architects & 6 & 2.4 \\
\hline 3 & Higher Economic Education & 34 & 13.6 \\
\hline 4 & $\begin{array}{l}\text { Higher } \\
\text { Education (unspecified) }\end{array}$ & 52 & 20.8 \\
\hline 5 & High School Education & 107 & 42.8 \\
\hline & TOTAL & 250 & 100.0 \\
\hline
\end{tabular}


Professional access of woodworking engineers to the labor market

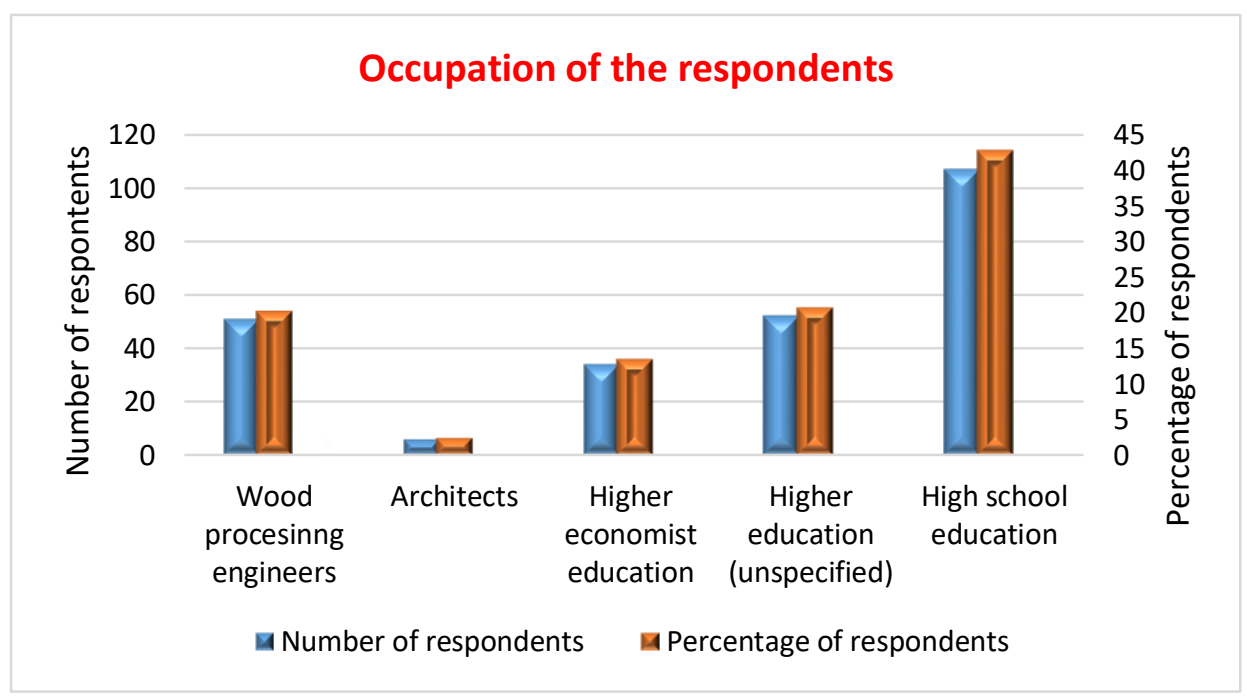

Figure 1. Occupation of the respondents.

Table 2. Engineers surveyed, employed and needs for engineers

\begin{tabular}{|c|c|c|}
\hline \multicolumn{3}{|c|}{ Engineers surveyed, employed and needs } \\
\hline Engineers surveyed & Engineers employed & Needs for engineers \\
\hline 51 & 75 & 94 \\
\hline
\end{tabular}

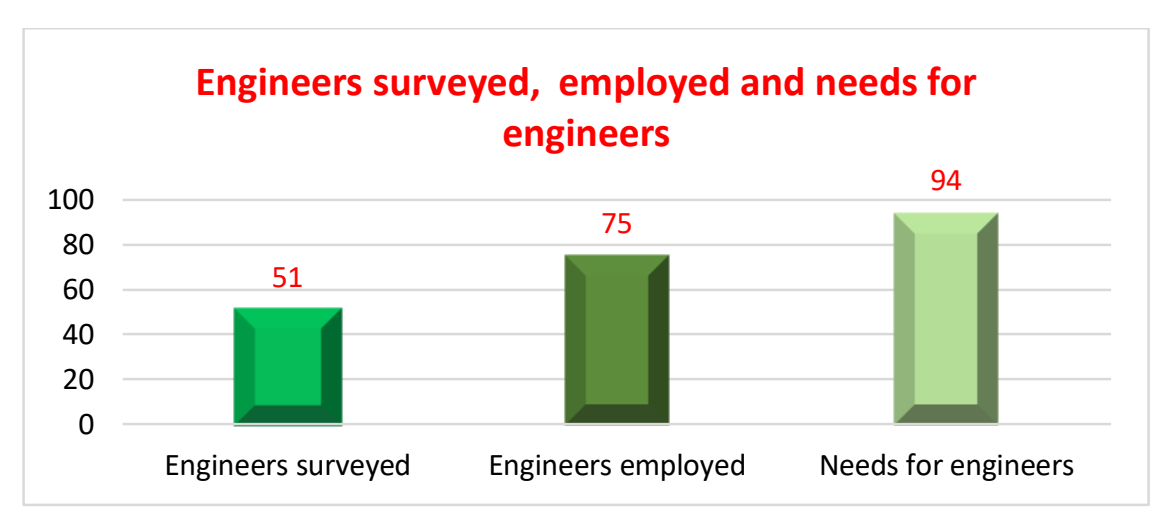

Figure 2. Engineers surveyed, employed and needs for engineers

About $50 \%$ of the engineers employed are located in Tirana. There are $8 \%$ of them in Durres and $7 \%$ in Fushe-Kruje. The engineers in Elbasan, Berat, Kamëz are by $4 \%$ and in Shkodra, Fier, Vlora by $2.7 \%$.

As regards the needs for wood processing engineers, there are demands throughout the country. Again about $17 \%$ of the needs are concentrated in Tirana, 12\% in Fushe Kruje, 6\% in Kamëz and 5\% in 
Book of Proceedings

International Conference on Architecture and Spatial Planning

Lezha. In cities like; Elbasan, Kruje, Durres the needs are for $4 \%$. Other cities result with $3 \%$ of the needs.

\section{Results}

Respondents provided their evaluation on the entire curricula of the Department of Wood Industry for both levels of study, Bachelor and Master.

Wood processing engineers who graduate in the Department of Wood Industry gain knowledge of various professional and scientific fields. To get the results it was made the grouping of knowledge by fields.

- Vocational knowledge

- $\quad$ Design and scientific knowledge

- Management and organizational knowledge

- Knowledge of new technologies

- $\quad$ Knowledge of the field of business, market and marketing

- $\quad$ General training knowledge

Through a screening question we aimed at receiving an opinion from the respondents on the field of specialization of engineers. To this point we asked respondents the ranking by importance of these fields assessing them with the numbers from 1 to 6 , where 1 is the highest rating and 6 the lowest. The surveying result for this point is given in table no. 3 .

Table 3. Some elements of the qualitative requirements of wood processing engineers' training

\begin{tabular}{|c|c|c|c|c|c|}
\hline No & $\begin{array}{l}\text { Components of Engineering } \\
\text { Qualification }\end{array}$ & $\begin{array}{l}\text { How many } \\
\text { times was } \\
\text { credited } \\
\text { with } 1\end{array}$ & $\begin{array}{l}\text { Cumulative } \\
\text { No. }\end{array}$ & $\begin{array}{l}\text { Assessment } \\
\text { in \% }\end{array}$ & $\begin{array}{c}\% \\
\text { Cumulative }\end{array}$ \\
\hline 1 & Vocational knowledge & 171 & 171 & 68.4 & 68.4 \\
\hline 2 & $\begin{array}{lll}\text { Design } & \text { and } & \text { scientific } \\
\text { knowledge }\end{array}$ & 32 & 203 & 12.8 & 81.2 \\
\hline 3 & Management knowledge & 18 & 221 & 7.2 & 88.4 \\
\hline 4 & $\begin{array}{lll}\begin{array}{l}\text { Knowledge } \\
\text { technologies }\end{array} & \text { of } & \text { new } \\
\end{array}$ & 16 & 237 & 6.4 & 94.8 \\
\hline 5 & $\begin{array}{l}\text { Knowledge of market and } \\
\text { marketing }\end{array}$ & 8 & 245 & 3.2 & 98 \\
\hline 6 & General training knowledge & 5 & 250 & 2 & 100 \\
\hline & TOTAL & 250 & 250 & 100 & 100 \\
\hline
\end{tabular}


Figure 3 shows the presentation through a Pareto chart.

\section{Assessment of some elements of enginieering training}

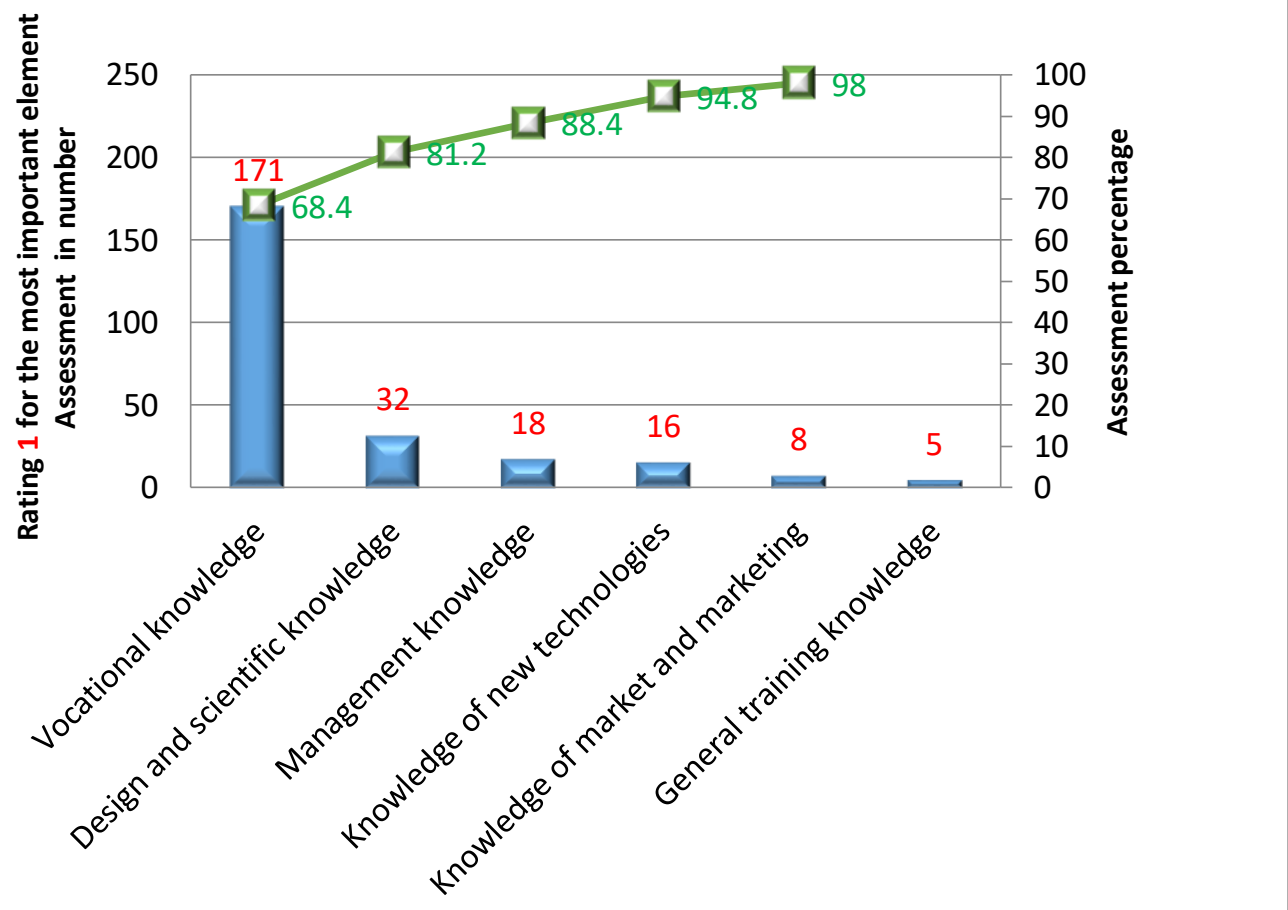

Figure 3. Some elements of the qualitative requirements of wood processing engineers' training assessed with 1

The above graphical presentation clearly and immediately shows the highest rating for the professional skills, followed by design and scientific research skills, thus the most "important" skills a wood processing engineer must have. This proves best the Pareto chart logic as well.

- Analysis of the survey data on the curricula

Regarding the curricula we have requested the respondents to give their assessment for all modules that are developed in the Department of Wood Industry. Wood processing engineers have been graduated in this curriculum for years. The assessment method in the questionnaire is by words and points, respectively; 5 as paramount, 4 as important, 3 as less important and 1 as unimportant. The assessment by points or words is for calculation convenience. In addition the subjects were grouped by similarity and areas. This with a view to concluding on the field of study on which the market is more interested in. Also, as resulted from the data analysis, subjects are more evaluated within the groupings. Table 4 provides us with the results of data analyzed for levels of the curricula in Bachelor and Master Studies.

Table 4. Evaluation of the curriculum by occupations of the respondents 
Book of Proceedings International Conference on Architecture and Spatial Planning

\begin{tabular}{|c|c|c|c|c|c|c|c|c|c|c|c|c|c|c|c|c|c|c|c|}
\hline \multirow{3}{*}{ 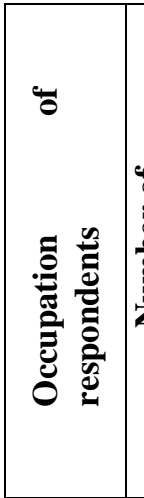 } & \multirow{3}{*}{ 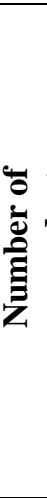 } & \multicolumn{11}{|c|}{ BACHELOR } & \multicolumn{6}{|c|}{$\begin{array}{c}\text { SCIENTIFIC } \\
\text { MASTER }\end{array}$} & \multirow[b]{2}{*}{$\begin{array}{c}\text { Overall } \\
\text { rating }\end{array}$} \\
\hline & & $\left\{\begin{array}{c}\text { Genc } \\
\text { ral } \\
\text { train } \\
\text { ng } \\
\text { subje } \\
\text { cts }\end{array}\right.$ & ei $\begin{array}{r}\text { Ba } \\
\text { g } \\
\text { tra } \\
\text { eng } \\
\text { eri } \\
\text { sub } \\
\text { t }\end{array}$ & $\begin{array}{l}\text { sin } \\
\text { iini } \\
\text { ig } \\
\text { ine } \\
\text { ing } \\
\text { jec } \\
\text { s } \\
\end{array}$ & $\begin{array}{r}\text { Bus } \\
\text { s } \\
\text { eco } \\
m \\
\text { orie } \\
\text { d } \\
\text { sub } \\
t\end{array}$ & $\begin{array}{l}\text { ine } \\
\text { s } \\
\text { no } \\
\text { y } \\
\text { nte } \\
\text { jec } \\
\text { jec } \\
\end{array}$ & $\begin{array}{r}\text { Voc } \\
\text { on } \\
\text { trai } \\
\text { sub } \\
\text { t }\end{array}$ & $\begin{array}{l}\text { cati } \\
\text { al } \\
\text { inin } \\
\text { g } \\
\text { jec } \\
\text { ts }\end{array}$ & & $\begin{array}{l}\text { ther } \\
\text { bjec } \\
\text { or } \\
\text { tion } \\
\text { al }\end{array}$ & & $\begin{array}{l}\text { The } \\
\text { erag } \\
\text { e } \\
\text { ating } \\
\text { for } \\
\text { achel } \\
\text { or }\end{array}$ & & $\begin{array}{l}\text { ener } \\
\text { al } \\
\text { lalifi } \\
\text { tion } \\
\text { bjec } \\
\text { ts }\end{array}$ & $\begin{array}{l}\text { Spe } \\
\text { ity } \\
\text { Pro } \\
\text { iona } \\
\text { Sub } \\
\text { s }\end{array}$ & 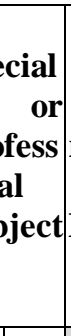 & $\begin{array}{r}\mathrm{Tl} \\
\text { ave } \\
\mathrm{e} \\
\text { reat } \\
\text { fo } \\
\mathrm{Ma}\end{array}$ & $\begin{array}{l}\text { The } \\
\text { erag } \\
\text { e } \\
\text { ating } \\
\text { cor } \\
\text { aster }\end{array}$ & \\
\hline & & \begin{tabular}{|c|c|}
$\mathrm{Me}$ & $\mathrm{S}$ \\
an & $\mathrm{E}$ \\
\end{tabular} & $\begin{array}{l}\mathrm{Me} \\
\text { an }\end{array}$ & $\mathrm{SE}$ & $\begin{array}{l}\mathrm{Me} \\
\text { an }\end{array}$ & $\mathrm{SE}$ & $\begin{array}{l}\mathrm{Me} \\
\text { an }\end{array}$ & SE & $\begin{array}{l}\mathrm{Me} \\
\text { an }\end{array}$ & $\mathrm{SE}$ & $\begin{array}{l}\mathrm{Me} \\
\text { an }\end{array}$ & $\mathrm{SE}$ & $\begin{array}{c}\text { Me } \\
\text { an }\end{array}$ & $\mathrm{SE}$ & $\begin{array}{c}\mathrm{Me} \\
\text { an }\end{array}$ & SE & $\begin{array}{c}\mathrm{Me} \\
\text { an }\end{array}$ & SE & \begin{tabular}{|c|c} 
Mea & SE \\
\end{tabular} \\
\hline \begin{tabular}{|c|} 
Wood \\
procesi \\
nng \\
enginee \\
rs \\
\end{tabular} & 51 & \begin{tabular}{c|c}
3.6 & 0 \\
9 & 0
\end{tabular} & $\begin{array}{c}4.0 \\
2\end{array}$ & $\begin{array}{c}0.0 \\
5\end{array}$ & {$\left[\begin{array}{c}3.9 \\
3\end{array}\right.$} & $\begin{array}{c}0.0 \\
5\end{array}$ & $\begin{array}{c}4.3 \\
6\end{array}$ & $\begin{array}{c}0.0 \\
3\end{array}$ & $\begin{array}{c}3.4 \\
8\end{array}$ & $\begin{array}{c}0.0 \\
5\end{array}$ & $\begin{array}{c}3.9 \\
5\end{array}$ & $\begin{array}{c}0.0 \\
2\end{array}$ & $\begin{array}{c}4.0 \\
5\end{array}$ & $\begin{array}{c}0.0 \\
5\end{array}$ & $\begin{array}{c}4.1 \\
7\end{array}$ & $\begin{array}{c}0.0 \\
4\end{array}$ & $\begin{array}{c}4.1 \\
2\end{array} \mid C$ & & $\begin{array}{l}4.030 .02 \\
0.03\end{array}$ \\
\hline $\begin{array}{c}\text { Higer } \\
\text { educati } \\
\text { on } \\
\text { (unspec } \\
\text { ified) } \\
\end{array}$ & 52 & $\left.$\begin{tabular}{c|c}
3.7 \\
5
\end{tabular}\right|$_{6} ^{0}$ & $\left\{\begin{array}{c}3.8 \\
2\end{array}\right.$ & $\begin{array}{c}0.0 \\
5\end{array}$ & $\begin{array}{c}3.8 \\
3\end{array}$ & $\begin{array}{c}0.0 \\
5\end{array}$ & $\begin{array}{c}4.2 \\
5\end{array}$ & $\begin{array}{c}0.0 \\
3\end{array}$ & $\begin{array}{l}3.3 \\
5\end{array}$ & $\begin{array}{c}0.0 \\
5\end{array}$ & $\begin{array}{c}3.8 \\
5\end{array}$ & $\begin{array}{c}0.0 \\
2\end{array}$ & $\begin{array}{c}3.9 \\
9\end{array}$ & $\begin{array}{c}0.0 \\
4\end{array}$ & $\begin{array}{c}3.9 \\
3\end{array}$ & $\begin{array}{c}4.0 \\
7\end{array}$ & 5 & & 3.880 .02 \\
\hline $\begin{array}{c}\text { Archite } \\
\text { cts }\end{array}$ & 6 & \begin{tabular}{c|c|c}
$\mathbf{4 . 0}$ & 0 \\
$\mathbf{1}$ & 1 \\
\end{tabular} & $\begin{array}{c}4.3 \\
6\end{array}$ & $\begin{array}{c}0.0 \\
9\end{array}$ & $\begin{array}{c}3.7 \\
9\end{array}$ & $\begin{array}{c}0.1 \\
4\end{array}$ & $\begin{array}{c}4.4 \\
4\end{array}$ & $\begin{array}{c}0.0 \\
7\end{array}$ & $\begin{array}{c}3.6 \\
2\end{array}$ & $\begin{array}{c}0.1 \\
2\end{array}$ & $\begin{array}{c}4.0 \\
9\end{array}$ & $\begin{array}{c}0.0 \\
5\end{array}$ & $\begin{array}{c}4.0 \\
7\end{array}$ & $\begin{array}{c}0.1 \\
4\end{array} \mid$ & $\begin{array}{c}3.9 \\
5\end{array}$ & $\begin{array}{c}4.3 \\
7\end{array}$ & $\mid \begin{array}{c}4.0 \\
2\end{array}$ & hr & 4.080 .04 \\
\hline $\begin{array}{c}\text { Higer } \\
\text { educati } \\
\text { on } \\
\text { econom } \\
\text { ists }\end{array}$ & 34 & $\begin{array}{ccc}3.5 & 0 \\
2 & 0 \\
9\end{array}$ & $\begin{array}{c}3.9 \\
9\end{array}$ & $\begin{array}{c}0.0 \\
6\end{array}$ & $\begin{array}{c}3.7 \\
6\end{array}$ & $\begin{array}{c}0.0 \\
7\end{array}$ & $\begin{array}{c}4.1 \\
9\end{array}$ & $\begin{array}{c}0.0 \\
4\end{array}$ & $\begin{array}{l}3.2 \\
2\end{array}$ & 0.0 & $\begin{array}{c}3.7 \\
8\end{array}$ & $\begin{array}{c}70.0 \\
3\end{array}$ & $\begin{array}{c}3.7 \\
9\end{array}$ & $\begin{array}{c}0.0 \\
6\end{array}$ & $\begin{array}{c}4.0 \\
2\end{array}$ & $\begin{array}{c}4.2 \\
8\end{array}$ & \begin{tabular}{c|c}
3.9 & 0 \\
2 & 0
\end{tabular} & 0. & $\mathbf{8 . 8 7} 0.02$ \\
\hline $\begin{array}{c}\text { High } \\
\text { school } \\
\text { educati } \\
\text { on } \\
\end{array}$ & 107 & $\left(\begin{array}{c}3.7 \\
1 \\
1 \\
4\end{array}\right.$ & $\begin{array}{c}3.9 \\
8\end{array}$ & 3 & 9 & 3 & 8 & $\begin{array}{c}0.0 \\
2\end{array}$ & $\begin{array}{l}3.1 \\
7\end{array}$ & $\begin{array}{c}0.0 \\
4\end{array}$ & $\begin{array}{c}3.8 \\
4\end{array}$ & $\begin{array}{c}0.0 \\
1\end{array}$ & $\begin{array}{c}3.8 \\
9\end{array}$ & $\begin{array}{c}0.0 \\
3\end{array}$ & $\begin{array}{c}3.9 \\
5\end{array}$ & $\begin{array}{c}0.0 \\
3\end{array}$ & $\begin{array}{c}3.9 \\
3\end{array}$ & 0. & 3.860 .01 \\
\hline
\end{tabular}




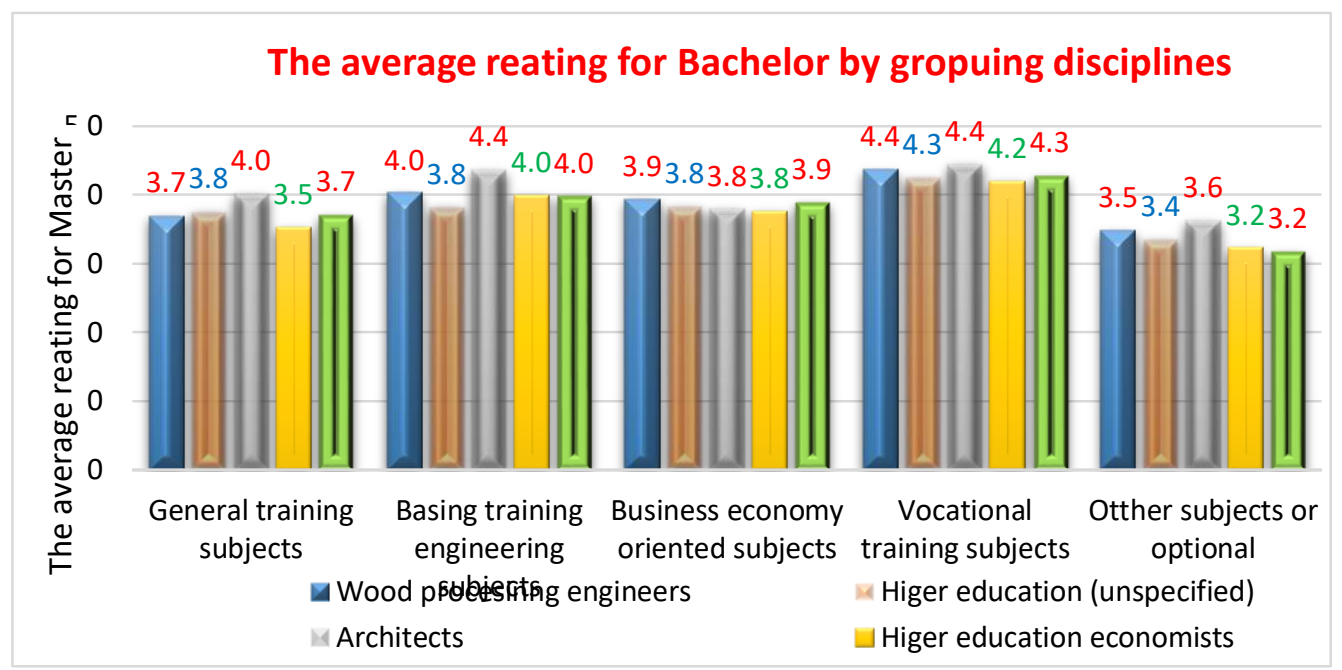

Figure 4. Evaluation of the Bachelor curriculum by occupations of the respondents

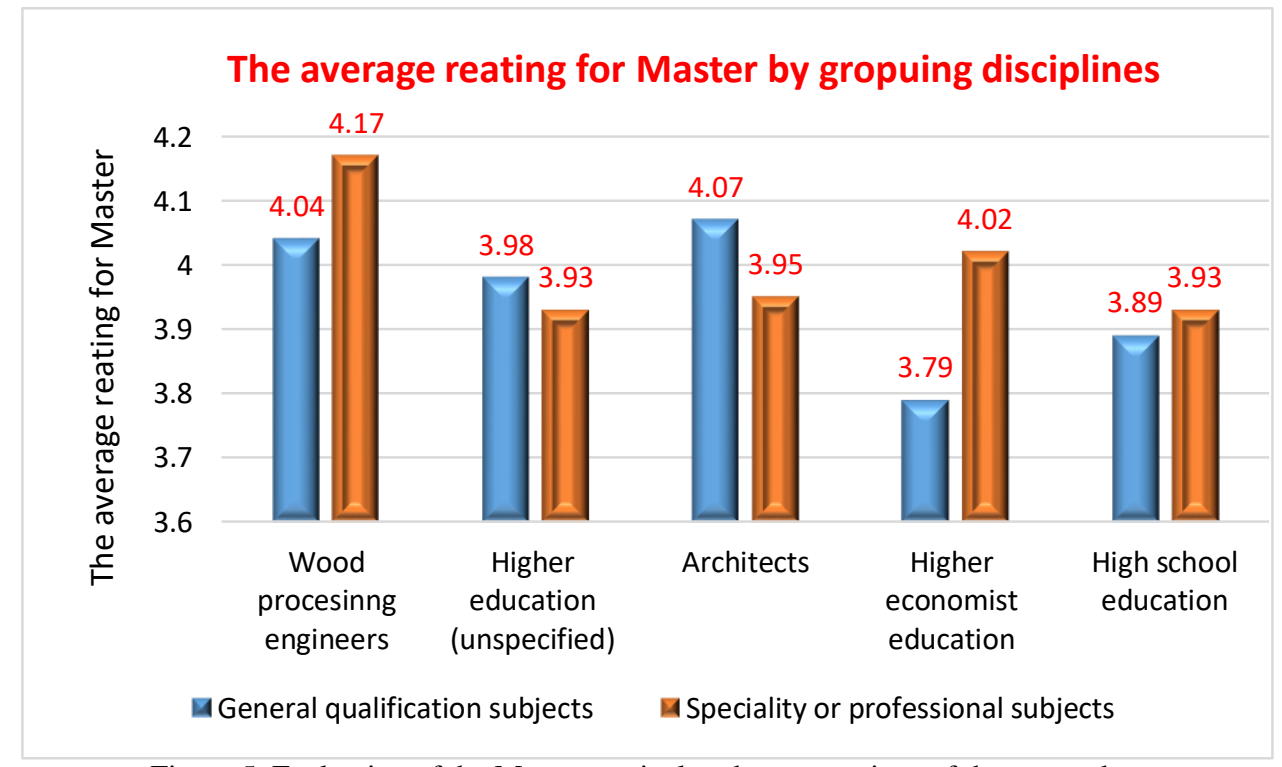

Figure 5. Evaluation of the Master curriculum by occupations of the respondents

As shown in the above table we have drawn a division to present the assessment given by respondents divided by occupation. For each group it was given the average rating and the standard error. To better meet the information we have presented the general assessment for each grouping. 
Generally, the highest rating for all the curricula is given by architects. Afterwards, wood processing engineers provide the highest rating. A lower rating is provided by respondents with secondary education. The curriculum is less rated by respondents with secondary education.

As a group of subjects are rated higher those of vocational training. Then, the list goes on with the engineering subjects of basic and general training. Later are rated the economy and business oriented subjects and other subjects that are practically elective.

\section{Conclusions}

Currently in Albania, the largest number of wood processing entities is comprised by small to medium businesses that produce and trade in furniture and other wooden products. A large number of them works with semi-finished materials, chipboard and MDF (Medium Density Fiberboard). Generally, the Wood Processing Industry in Albania is more developed in large cities. Recently, there is a tendency of the development of "various services" mainly, small orders wherein take place some of the technological operations.

About 50\% of wood processing engineers are employed in Tirana, $8 \%$ of them in Durres, $7 \%$ in FusheKruje and in Elbasan, Berat and Kamëz by $4 \%$ of them.

The most obvious needs for wood processing engineers are in Tirana (17\%), in Fushe-Kruje $12 \%$ and $6 \%$ in Kamëz. This also shows for a tendency of development of this industry.

Recent years the university education has changed a lot due to the development of information technology. However, the study shows the need for continuous improvement in several directions.

In the opinion of the respondents, in order to be closer to the market, the Faculty should prepare professionally skilled wood processing engineers. Engineers must be trained in terms of knowledge on new technologies and mainly for their application in practice.

Market requires studies focus towards the field of architecture and interior design. This is indicated by the maximum rating that respondents provide to subjects related with projection and design.

Respondents evaluate as highest in both levels of study (Bachelor and Master) the vocational training of engineers related to the wood processing technology. According to them, the engineers must have their professional knowledge up to date, applied in practice, constantly improving the technology innovations.

\section{Recommendations}

- Wood Industry Department should give a special significance to the new curricula. Besides focusing on students (for the period of study) it should also be followed the progress of graduated engineers, the monitoring of their careers. Also, it should also be followed their consent or reaction to vacancies, as well as their recruitment by employers.

- Vocational training of wood processing engineers according to the requirements of the labor market would create potential employment opportunities for the latter and facilities to the labor market itself, always evolving and in constant change.

- The University Staff of Excellence, more than anyone else would take the process forward. Excellence is what respects and expands the best standards and gives meaning to professions and development. 
Professional access of woodworking engineers to the labor market

\section{References:}

1. Research methods, Bob Matthews dhe Liz Ross (Birmingham University).

2. The strategic plan of the Agricultural University of Tirana. Tirana 2005

3. The need for Wood Processing engineers in the manufacturing entities of Tirana. Topuzi R Bejtja A.

4. Elements of engineering training and their assessment by the labor market. Topuzi R Bejtja A Peri L.

5. Distribution of wood processing industry in Albania, R. Topuzi, A. Bejtja, L. Peri, IJEIR, Volume-5, Issue-2, March 2016. 